ARTIGO RETRATADO

DOI: https://doi.org/10.21723/riaee.v17i3.17248

\title{
PESSOAS COM DEFICIÊNCIA (PcD) EGRESSAS DE UMA FORMAÇÃO PROFISSIONAL: TRABALHO E EDUCAÇÃO
}

\section{PERSONAS CON DISCAPACIDADES (PwD) EGRESADAS DE UNA FORMACIÓN PROFESIONAL: TRABAJO Y EDUCACIÓN \\ PEOPLE WITH DISABILITIES (PwD) EGRESSED FROM A VOCATIONAL TRAINING: WORK AND EDUCATION}

RESUMO: Este artigo tem por objetivo apresentar, na concepção de Pessoas com Deficiência (PcD) egressas de formação profissional, a contribuição dessa formação para sua inclusão no mundo do trabalho. Foi realizada pesquisa exploratória e descritiva, com abordagem qualitativa de corte transversal. Os procedimentos foram: pesquisa bibliográfica, documental e de campo. Roteiro semiestruturado de entrevistas foi o instrumento aplicado na coleta de dados. Foram realizadas 28 entrevistas com PcD egressas da formação profissional do SENAI/SP e aplicada a técnica de análise de conteúdo. O software NVivo 12 foi utilizado na análise dos dados. Os resultados indicam que, na concepção dos egressos, a formação profissional possibilita a descoberta de suas capacidades e potencialidades; permite que sejam produtivos, interajam no ambiente de trabalho e contribuam com a sociedade, sentindo-se incluídos. Constatou-se que houve impactos positivos na vida de todos os sujeitos, relacionados ao resgate de valores como autoestima, autonomia e cidadania.

PALAVRAS-CHAVE: Educação profissional. Pessoa com deficiência. Análise de conteúdo.

1 Fundação Oswaldo Cruz (FIOCRUZ), Rio de Janeiro - RJ - Brasil. Pesquisadora Titular. Bolsista de Produtividade em Pesquisa do CNPq - Nível 1A. Doutorado em Saúde Pública (FIOCRUZ). ORCID: https://orcid.org/0000-0001-6187-9301. E-mail: cecilia@claves.fiocruz.br

2 Universidade de Brasília (UnB), Brasília - DF - Brasil. Professor Titular Aposentado, Departamento de Sociologia. Bolsista de Produtividade em Pesquisa do CNPq - Nível 1B. Pós-Doutorado pela Universidade da Califórnia em Los Angeles (UCLA). E-mail: lepp@rc.unesp.br

${ }^{3}$ Centro Universitário do Sul de Minas (UNIS), Varginha - MG - Brasil. Pesquisador no Departamento de Pesquisa. Bolsista PNPD/CAPES. Doutorado em Educação Escolar (UNESP). ORCID: https://orcid.org/00000003-1171-217X E-mail: r.silva@unesp.br 
RESUMEN: Este artículo tiene como objetivo presentar, en la concepción de los graduados de personas con discapacidades (PwD) de la formación profesional, la contribución de esta formación a su inclusión en el mundo del trabajo. Se llevó a cabo una investigación exploratoria y descriptiva, con un enfoque transversal cualitativo. Los procedimientos fueron: investigación bibliográfica, documental y de campo. El guión de entrevista semiestructurada fue el instrumento aplicado en la recopilación de datos. Se llevaron a cabo 28 entrevistas con graduados de PwD de la formación profesional SENAI / SP y se aplicó la técnica de análisis de contenido. Se usó el software NVivo 12 para analizar los datos. Los resultados indican que, en la concepción de los graduados, la formación profesional les permite descubrir sus habilidades y potencialidades; les permite ser productivos, interactuar en el entorno laboral y contribuir a la sociedade.

PALABRAS CLAVE: Educación profesional. Persona discapacitada. Análisis de contenido.

ABSTRACT: This article aims to present, in the conception of People with Disabilities (PcD) graduates of professional training, the contribution of this training to its inclusion in the world of work. An exploratory and descriptive research was conducted, with a qualitative cross-sectional approach. The procedures were: bibliographic, documentary and field research. Semi-structured interview script was the instrument applied in data collection. Twenty-eight interviews were conducted with PcD graduates from the professional training of SENAI/SP and applied the technique of content analysis. The NVivo 12 software was used in data analysis. The results indicate that, in the conception of graduates, professional training enables the discovery of their abilities and potentialities; allows them to be productive, interact in the work environment and contribute to society, feeling included. It was found that there were positive impacts on the lives of alt subjects, related to the rescue of values such as self-esteem, autonomy and citizenship.

KEYWORDS: Professional education. Person with special needs. Content analysis.

\section{Introdução}

O direito das pessoas com deficiência $(\mathrm{PcD})$ é um tema debatido e discutido há muito em toda a sociedade, mas, apesar das conquistas dos últimos anos, ainda se percebe uma situação de exclứão em relação aos direitos básicos do cidadão em todo o mundo.

Yários documentos evidenciam que pessoas com deficiência experimentam piores resultados socioeconômicos e maior pobreza do que as pessoas não deficientes (OMS, 2011); assim, a deficiência é cada vez mais considerada uma questão de direitos humanos e por isso há uma preocupação mundial sobre a inclusão.

A Convenção sobre Direitos das Pessoas com Deficiência das Nações Unidas (CDPD) (BRASIL, 2008) estabelece em seu artigo dezenove que as pessoas com deficiência devem ter o igual direito de viver na comunidade, com a mesma liberdade de escolha que as demais 
pessoas, e que os países tomarão medidas efetivas e apropriadas para facilitar a essas pessoas o pleno gozo desse direito e sua plena inclusão e participação na comunidade.

Ao longo dos anos, políticas públicas e leis foram elaboradas e promulgadas no Brasil para garantir o direito da pessoa com deficiência (PcD) enquanto cidadã. Em 2015 foi promulgada a Lei 13.146/15 - Lei Brasileira de Inclusão (LBI) - Estatuto da pessoa com deficiência. A LBI tem como base a Convenção Sobre os Direitos da Pessoa Com Deficiência (BRASIL, 2008), que estabelece, em seu artigo primeiro, que PcD são aquelas pessoas que possuem impedimentos de natureza física, intelectual ou sensorial que podem dificultar ou mesmo obstruir sua participação plena na sociedade.

Cabe ressaltar, entretanto, que a efetiva prática desses instrumentos ainda deixa a desejar, uma vez que implica na quebra de resistências e, sobretudo, no desprendimento de preconceitos e valores culturais desde há muito arraigados na sociedade. Há a necessidade de uma educação inclusiva, que possibilite a aquisição de conhecimentos, habilidades e atitudes para a vida, tendo em vista os quatro pilares da educação, istoé, saber, saber fazer, saber conviver e saber ser (DELORS, 1998).

Segundo Silva (2019), muitas são as facetas das desigualdades de gênero e estas contam com diversos meios de propagação dos ideais de divisão cultural e social entre homens/meninos e mulheres/meninas, sendo estes reconfigurados na sociedade; vemos na atualidade a grande influência midiática e dós meios eletrônicos como smartphones, internet e a publicidade, que reinventam as formas de propagação da desigualdade e muitas vezes dão um ar de superação, apontando para um poder feminino que está longe de ser alcançado plenamente.

Considerando o trabalho como possibilidade de efetivação do direito de participação social e do exercício dá cidadania, o presente artigo apresenta, na concepção de pessoas com deficiência, a contribuição dos cursos de formação profissional para a empregabilidade.

\section{Inclusão pela Educação Profissional}

A história da pessoa com deficiência $(\mathrm{PcD})$ no Brasil apresentou um percurso similar ao processo no resto do mundo, iniciando-se com uma fase de intolerância, onde a pessoa com deficiência era eliminada; depois, uma fase de invisibilidade, isto é, a pessoa com deficiência era segregada do convívio social e colocada em instituições de acolhimento; uma fase de assistencialismo, com organizações civis se ocupando do cuidado dessa pessoa; e uma última fase orientada pelos direitos humanos, momento em que emergiram direitos 
direcionadores à inclusão social, como o direito social à educação e ao trabalho. Mesmo nesta última fase houve um período onde o objetivo foi o de integração da pessoa com deficiência e, atualmente, o objetivo é que haja de fato uma inclusão deste indivíduo na sociedade. Este objetivo será alcançado quando tivermos uma sociedade inclusiva, segundo Sassaki (2010). Para o mesmo autor (2010), a sociedade inclusiva

[...] é aquela onde a sociedade e a pessoa com deficiência procuram adequarse mutuamente tendo em vista a equiparação de oportunidades e consequentemente, uma sociedade para todos. A inclusão [...] significa que a sociedade deve adequar-se às necessidades da pessoa com deficiência para que esta possa desenvolver-se em todos os aspectos de sua vida (SASSAKI, 2010, p. 175).

Muitas dessas mudanças ocorrem porque as pessoas com deficiência estão se descobrindo como Pessoas, cidadãs de primeira classe, que possuem limitações e não defeitos ou doenças e que querem ter o direito de exercer sua cidadania e construir sua identidade. É notório também que a elaboração de instrumentos legais, por si só, não garante a mudança de atitude da sociedade em relação às pessoas com deficiência.

Segundo Minayo (2006), a sensibilização en relação à relevância do tema como pauta para ação de saúde se inicia pioneiramente com a questão da violência contra crianças. Embora existam alguns documentos históricos que mostrem, desde a Antiguidade, uma preocupação da sociedade em regular a subministração de castigos e maus tratos na infância, os primeiros textos que vinculam este tipo de violência com a saúde procedem dos levantamentos de Tardieu em 1880. Nos anos 60 do século passado, por meio de textos e debates, os profissionais de saúde começaram a fazer denúncias sistemáticas sobre as várias modalidades de viólência contra crianças e adolescentes, e sua influência negativa para o crescimento e o desenvolvimento das vítimas. Uma década depois de os pediatras Kempe et al. cunharem a expressão "síndrome do bebê espancado", vários profissionais, em grande parte dos países, passaram a reconhecer e a diagnosticar este tipo de agravo como um problema/de saúde. Programas de prevenção primária e secundária e intervenções, principalmente nas dinâmicas familiares responsáveis pela maioria das agressões, negligências e abusos psicológicos, instituíram-se na pauta de serviços de instituições públicas, privadas e ONGs.

A inclusão social é um processo bilateral no qual as pessoas ainda excluídas, por quaisquer motivos, inclusive a deficiência, e a sociedade buscam, em parceria, equacionar problemas, encontrar soluções e efetivar a equiparação de oportunidades para todos (SASSAKI, 2003). Neste modelo, conhecido como modelo social da deficiência, os 
problemas da pessoa com deficiência estão na sociedade, que é chamada a perceber que são esses problemas que causam à pessoa com deficiência incapacidades ou desvantagens no desempenho de seu papel social (SASSAKI, 2010).

Segundo Silva (2014), as empresas que se propuserem a ser inclusivas deverão estar dispostas a investir em tecnologias assistivas, diagnósticos de áreas e atividades possíveis de adaptação. Além de trabalhar mudanças em práticas administrativas, deverão promover ações para a sensibilização e capacitação de equipe para recebimento e inclusão efetiva da pessoa com deficiência. Para que haja a inclusão é preciso cooperação.

O Censo Demográfico de 2010, realizado pelo IBGE, contabilizou 45.606.048 de brasileiros que declararam possuir algum tipo de deficiência ${ }^{4}$. De acordo com o Decreto Federal 5.296/2004, as deficiências podem ser classificadas em deficiência física, auditiva, visual, intelectual ou múltipla e estavam assim identificadas no Censo: pelo menos uma das deficiências $23,9 \%$, deficiência visual $18,6 \%$, auditiva $5,1 \%$, motora $7 \%$ e intelectual $1,4 \%$.

De acordo com dados da Relação Anual de Informações Sociais (RAIS) do ano de 2017, do total de 46,3 milhões de vínculos empregatícios formais, 441,3 mil foram declarados como pessoas com deficiência, o equivalente a 1,0\% do contingente de empregos formais no Brasil. A tabela 1 apresenta a distribuição dos empregos por tipo de deficiência.

Tabela 1 - Distribuição dos Empregos Formais das PcD em 2017

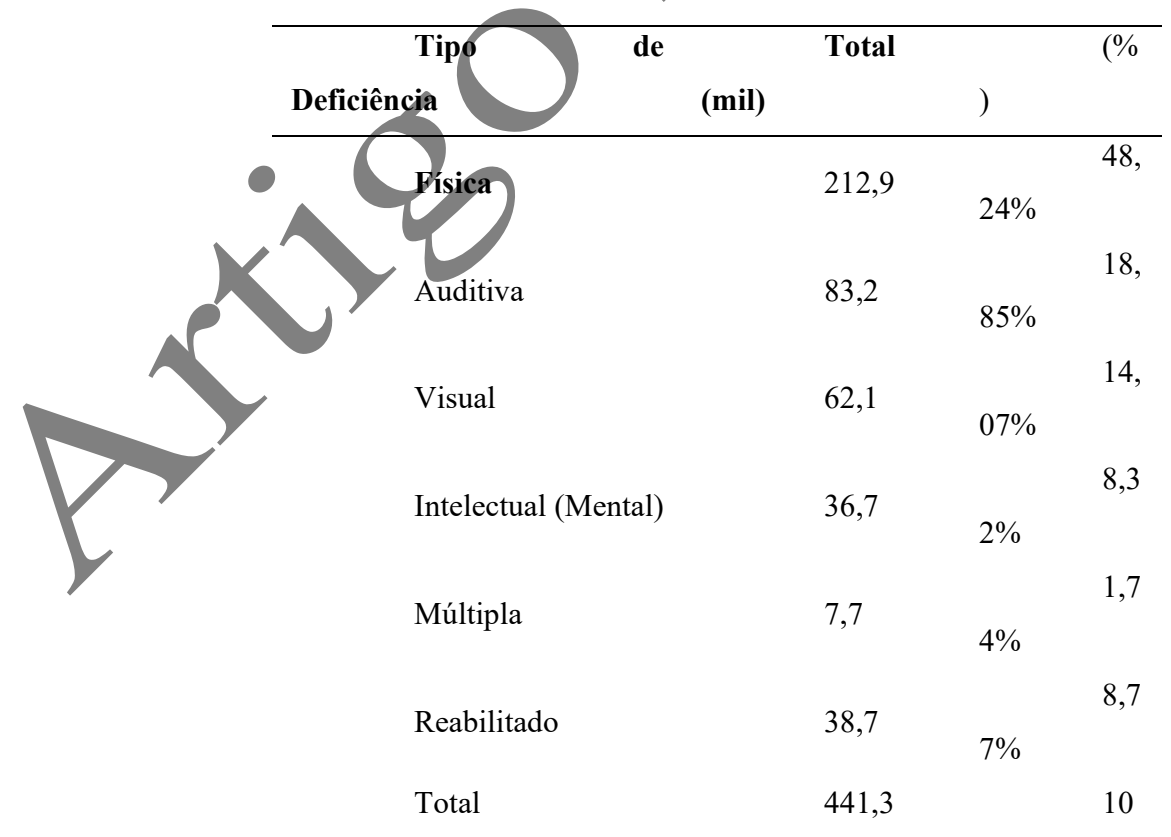

${ }^{4}$ O Instituto Brasileiro de Geografia e Estatística - IBGE lançou, no $2^{\circ}$. trimestre de 2018, o Panorama nacional e internacional da produção de indicadores sociais: grupos populacionais específicos e uso do tempo, com mudanças na forma de interpretação dos dados do último Censo 2010. Nesse novo documento, o IBGE indica a proporção das pessoas com deficiência na população brasileira de $6,7 \%$, correspondendo em números absolutos a 12 milhões e 748 mil brasileiros. 
Fonte: Adaptado de Ministério do Trabalho (MTb)/RAIS (2017)

Comparando-se o número de $\mathrm{PcD}$ existente no país e a quantidade de $\mathrm{PcD}$ com empregos formais, verifica-se que é incipiente o acesso das $\mathrm{PcD}$ ao mercado de trabalho. Existem barreiras que impedem ou, no mínimo, dificultam as PcD de exercerem seu direito ao trabalho. Faz-se prioridade a eliminação de barreira e a acessibilidade de todos, independentemente de quaisquer características associadas às deficiências.

Garcia e Galvão Filho (2012) definem que a questão da acessibilidade, de modo especial para a $\mathrm{PcD}$, deve ser tratada como "um direito fundamental que possibilita o exercício pleno da cidadania e o acesso a outros direitos básicos como aprender, comunicarse, trabalhar, divertir-se, etc." (GARCIA; GALVÃO FILHO, 2012, p. 60).

\section{Educação Profissional e Empregabilidade}

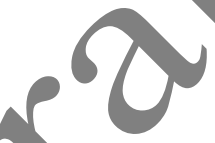

A Lei de Diretrizes e Bases da Educação nacional (LDB), instituída em 1996, estabelece as diretrizes e as regras que nortejam a Educação no Brasil. Em 2008 foi promulgada a Lei 11.741, que traz uma nova redação para a LDB. A partir daí, a expressão Educação Profissional passa a ser designada como Educação Profissional e Tecnológica (EPT). A LDB, nos artigos 39 a 42, prevê a integração da EPT com os diferentes níveis e modalidades da Educação e às dimensões do trabalho, da ciência e da tecnologia. Também define a abrangência dos cursos desta modalidade educacional: cursos de formação inicial e continuada ou qualificação profissional; de educação profissional técnica de nível médio e de educação profissional tecnológica de graduação e pós-graduação, organizados de forma a propiciar o aproveitamento contínuo e articulado dos estudos (BRASIL, 1996). A educação profissional passa a ser entendida por meio de uma nova dimensão, voltada para o desenvolvimento pessoal e social do educando e para as exigências do mundo do trabalho em permanente transformação (SALES; OLIVEIRA, 2011).

Sales e Oliveira (2011) afirmam que:

É necessário, portanto, construir um processo de socialização e qualificação para o trabalho, por meio da apropriação de saberes relativos à ciência, às técnicas, às tecnologias e às múltiplas culturas, essenciais ao mundo do trabalho, que integra novas bases científicas e tecnológicas, e demanda, cada vez mais, o desenvolvimento intelectual dos trabalhadores (SALES; OLIVEIRA, 2011, p. 1). 
Lima e Cappelle (2013) afirmam que cada indivíduo possui um conjunto de saberes que lhe é particular, resultado de um histórico de oportunidades de aprendizagens anteriores e das suas características pessoais; essas particularidades devem ser consideradas em sala de aula para se adotar medidas adaptativas que favoreçam a aprendizagem e promovam a inclusão.

Não basta ser inserido no mercado de trabalho, é preciso ter condições de se manter ativo no mundo do trabalho. Abbud (2017, p. 34) reflete que esse cenário evoca uma nova ordem que "concebe, estrutura, organiza, pensa e significa modos de ser profissional", isto é, seu estado de empregabilidade.

Alkmim (2015), em seu estudo bibliográfico sobre o conceito de empregabilidade, identifica que não há um consenso sobre o termo, sendo o mesmo objeto de controvérsias. Minarelli (1995, p. 11) a descreve como a capacidade de o trabalhador "dar e conseguir emprego para os seus conhecimentos, habilidades e atitudes intencionalmente desenvolvidos pela educação e treinamento, sintonizados com as necessidades domercado de trabalho".

É controversa a concepção da empregabilidade como uma capacidade individual, já que esse conceito difunde a ideia de que o desemprego está associado à suposta falta de preparo e à inadequação dos perfis de qualifícação dos trabalhadores frente às novas exigências do mercado de trabalho, e não à falta de oferta de empregos.

A educação, no entanto, aparece como elemento comum em todas as concepções sobre empregabilidade e é destacada como fator de vital importância para a aquisição dos conhecimentos que o indivíduo necessita para se manter ativo no mundo do trabalho, conforme destaca Alkmim (2015), o que também se observa para o aluno da educação especial.

\section{Método}

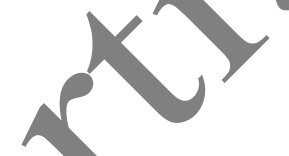

Esta pesquisa, de natureza exploratória e descritiva, tem uma abordagem qualitativa de corte transversal, de 21/08/2018 a 13/12/2018. Os procedimentos utilizados na pesquisa foram: pesquisa bibliográfica, documental, para levantamento de documentos relacionados aos programas de formação profissional do Serviço Nacional de Aprendizagem Industrial (SENAI), e de campo, para melhor entendimento da realidade vivenciada pelo egresso com deficiência na busca da sua inserção profissional e empregabilidade; foi aplicada por meio de entrevistas com egressos com deficiência de cursos de formação profissional do SENAI Departamento Regional São Paulo (SENAI-SP). 
Os dados foram coletados no SENAI - Serviço Nacional de Aprendizagem na Indústria. Um complexo de educação profisssional, cujos cursos formam profissionais para 28 áreas da indústria brasileira, desde a iniciação profissional até a graduação e pós-graduação tecnológica. No estado de São Paulo a rede do SENAI conta com 169 unidades, sendo 95 escolas fixas e 74 móveis. É também uma instituição de Educação Profissional que recebe PcD por meio do Programa SENAI de Ações Inclusivas (PSAI), criado em 1999 (SENAI, 2019; SENAI, 2019a). No final de 2010, o SENAI-SP criou o Programa Incluir, com o objetivo de investir nas ações inclusivas e apoiar as indústrias paulistas no cumprimento integral da Lei de Cotas (GIL, 2012).

Foram realizadas 28 entrevistas com o uso de roteiro semiestruturado para coleta de dados, com o propósito de obter as opiniões dos egressos nas situações reais de empregabilidade. As entrevistas foram gravadas e transcritas integralmente no editor de texto Word ${ }^{\circledR}$ (Office 2010) da Microsoft. As entrevistas com PcD auditiva foram feitas com a utilização de notebook e do editor de texto Word® (Office 2010) da Microsoft. Todas os participantes assinaram o Termo de Consentimento Livre e Esclarecido e a Cessão de Direitos sobre Depoimento Oral, seguindo as orientaçơes da Resolução do Ministério da Saúde número 466, de 12 de dezembro de 2012 .

Foi utilizada a técnica de Análise de Conteúdo com a finalidade de descrever, interpretar os conteúdos das entrevistas, ajuddar a reinterpretar as mensagens e a atingir uma compreensão de seus significados, num nível que vai além de uma leitura comum (BARDIN, 2016), utilizando-se o Software NVivo $12 ®(Q S R$ International) para o suporte e tratamento das categorias temáticas. Este software é projetado para auxiliar a organizar, analisar e encontrar informaçốes em dados não estruturados ou qualitativos como: entrevistas, respostas abertas de pesquisa, artigos, mídia social e conteúdo web (CAVALCANTI et al., 2017).

\section{Análise e discussão dos resultados}

Os dados levantados nas entrevistas possibilitaram a organização de características sociodemográficas do grupo estudado. Em relação à idade, apesar da legislação não limitar a idade para a entrada e permanência nos Programas de Aprendizagem para $\mathrm{PcD}, 46 \%$ dos alunos se constituíram de jovens, com idade entre 18 e 24 anos. Houve prevalência do sexo masculino (57\%), distribuído por todas as faixas etárias e tipos de deficiência. Dados relativos ao tipo de deficiência mostram prevalência das deficiências sensório-motoras (física, auditiva e visual), correspondendo a $82 \%$ do grupo estudado. 
Egressos participantes de Cursos de Aprendizagem Industrial com duração de 3 anos formam o grupo com maior participação no estudo (79\%). Estes egressos participaram, em diversas escolas do SENAI, de um projeto específico dentro dos Programas de Aprendizagem (Programa Meu Novo Mundo), cujo término do curso ocorreu ao longo do ano de 2018, facilitando assim o contato, tanto das escolas, quanto da pesquisadora.

Em relação à situação laboral, houve prevalência dos egressos empregados na área da formação profissional (71\%); porém $25 \%$ do grupo estudado ainda estava fora do mundo do trabalho. Para a exploração dos dados foram cruzados os dados relacionados a tipo de deficiência e a situação laboral (figura 1) e a situação laboral e a duração do curso.

Figura 1 - Gráfico da Distribuição dos egressos por situação laboral e tipo da deficiência

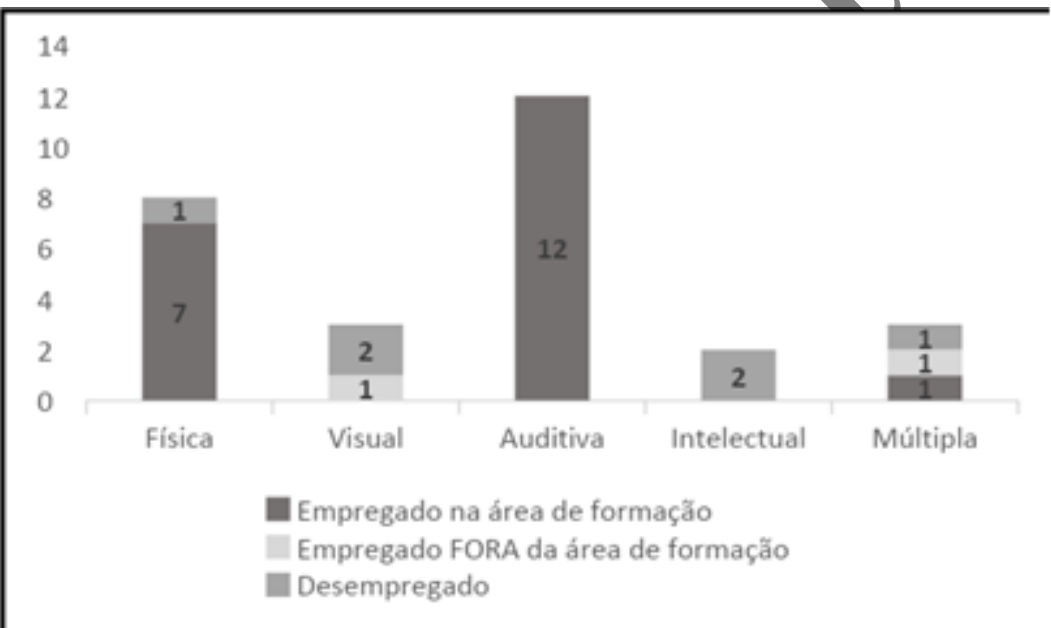

Fonte: resultado da pesquisa

É possível ressaltar esse resultado a partir de relatos dos entrevistados:

Não fui contratada após o término do curso porque a empresa falou que foi

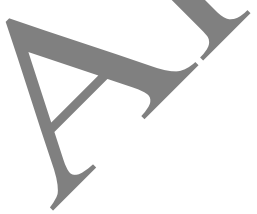
por causa da acessibilidade. O meu programa que é o NVDA, não é acessivel com a plataforma deles. (E-03, visual, desempregado).

Acredito que a empresa preferiu ficar com os auditivos, que, vamos dizer assim, dão um pouquinho menos de trabalho. Eles [a empresa] ainda têm um pouco de receio das pessoas com deficiência visual, por exemplo, de sofrer algum acidente, na locomoção dentro da empresa, porque não tá totalmente adaptável. O medo deles é um pouco por isso. (E-25, visual, desempregado).

Analisando-se a relação entre o tempo de duração do curso e a empregabilidade, verificou-se que o percentual de empregados na área da formação profissional que cursaram o programa em um ano correspondia a $67 \%$, e o percentual dos que cursaram em 3 anos a $71 \%$, 
não apresentando diferenças relevantes. A duração dos programas de aprendizagem é definida em função do tempo necessário para desenvolver no aprendiz as competências para o desempenho de um perfil profissional (SENAI, 2018). Assim, justifica-se que a variável duração do curso não seja relevante na empregabilidade dos egressos.

\section{Análises temático-categoriais}

A análise dos dados realizada ao longo da fase de exploração do material gerou categorias temáticas empíricas, com o propósito de se constituírem respostas ou pistas importantes ao objetivo desse estudo. Para a categoria Formação profissional, surgiram as seguintes subcategorias: i) benefícios adquiridos pela formação profíssional, ii) inclusão no ambiente escolar e iii) contribuições do SENAI para a empregabilidade dos sujeitos, descritas a seguir:

\section{Formação Profissional}

De acordo com Neves-Silva, Prais e Silveira (2015), a relação entre a educação inclusiva e a inclusão laboral é estreita. A educação inclusiva possibilita o convívio das pessoas com deficiência com as demais desde a infância, favorece um ambiente com menos preconceito e discriminação e, por consequência, a inclusão. A educação inclusiva também estimula a pessoa com deficiêneia a interagir com outros indivíduos, assim melhorando a relação que ela estabelecerá con a sociedade.

\section{Benefícios adquiridos pela formação profissional}

Quanto aos benefícios adquiridos pela formação profissional, como declarado por Johann (2011), os programas de Educação Profissional visam o desenvolvimento integral do ser humano, contemplando os aspectos emocionais, cognitivos, físicos, sociais e políticos, isto é, devem ir além da formação profissionalizante e contribuir para a formação de sujeitos sociais (OLIVEIRA, 2017).

A contribuição da formação para além da capacitação profissional pode ser observada pela identificação de benefícios para a vida pessoal por todos os egressos entrevistados e exemplificada nos relatos: 
Olha, ... me trouxe muito assim, acho que mais autonomia. Tomada de decisões. Eu era muito insegura. [...] A forma de conviver com as pessoas, como lidar com as pessoas. É a forma de saber lidar com o outro, como diferenciar do outro. Eu acho que tive muita superação nessa parte. (E-03, visual)

Para mim foi um pouco vergonhoso tenta mudar, minha atitude era ficar do lado para apresentar trabalho; mudou um pouquinho depois do curso e também outra coisa boa é que agora eu também ajudo minha mãe em casa [...] Eu tive uma mudança de certas atitudes, eu percebi que posso colaborar dentro de casa. (E-06, auditiva)

Portanto, ratifica-se as afirmações de Sales e Oliveira (2011) em relação à nova dimensão da educação profissional, orientada ao desenvolvimento pessoal e social do educando e às exigências do mundo do trabalho em permanente transformação. A concepção de autonomia, protagonismo, novas atitudes adquiridas a partir da formação recebida são evidenciadas nos relatos:

Eu comecei a ganhar autonomia, ganhei meu primeiro dinheirinho. Poder comprar uma mochila sozinho foi o ápice da minha vida; depois que eu participei do programa que eu vi a)mudança. De ganhar autonomia e independência.... De ganhar autonomia, para cuidar das minhas coisas. (E04 , física)

Minha vida era mais complicada... Depois que comecei a fazer o curso, mudou minha vida. Eu não tinha cultura, eu não tinha atitude, não tinha nada. Agora eu quero a minha vida melhor. Eu quero fazer faculdade, eu quero trabalhar, eu quero fazer tudo para minha vida agora. (E-05, auditiva)

Primeiro, pessoal, para mim, foi o que teve maior peso. Porque, para mim, eu não me aceitava como uma pessoa com deficiencia. Olhava para mim e, não, náo posso aceitar isso para minha vida [...]. Foi difícil porque eu não me aceitava como deficiente [...] foi uma experiência muito boa de conseguir enxergar as pessoas normal, ser deficiente para mim é normal. As pessoas têm pré-conceito, tem, mas começa de mim, eu me aceitar e as outras pessoas não importa se aceitar ou não. (E-14, auditiva)

Em relação aos benefícios da vida profissional, os egressos destacam a efetivação em rabalhos na área de formação e a aquisição de conhecimentos que ajudarão em sua mpregabilidade futura:

O curso me ajudou a me efetivar nesse trabalho [...]. O curso e as escolas foram um empurrãozinho para a gente começar a entrar e trabalhar sozinho e caminhar sozinho. (E-04, física).

É a oportunidade de trabalhar, que eu não tinha. Um monte de coisas, mas a oportunidade é a melhor. Responsabilidade! (E-02, física). 
Teve muita coisa que eu já sabia, mas eu aprendi muito mais [...]. Ajudou a pensar no meu negócio. (E-09, múltipla).

Ajudou muito para o futuro, no presente. o que eu estudei aqui vou conseguir aplicar num emprego no futuro. (E-10, intelectual).

A partir do momento em que a gente começa a estagiar na empresa, a gente sabe como funciona, qual é o processo, o trabalho em equipe, a parceria, $e$ como pessoa, você se sente mais independente, mais autônoma, tem seu próprio dinheiro para fazer suas coisas, [...]. Não ficar dependendo de outras pessoas. (E-13, física).

Embora o termo "empregabilidade" não tenha sido diretamente/mencionado por nenhum dos egressos como resultado da formação profissional, é possível afirmar, assim como proposto por Alkmim (2015), que a educação, que aparece como elemento comum em todas as concepções de empregabilidade, é de fato fonte de substancial importância para a aquisição dos conhecimentos que o indivíduo necessita para se manter ativo no mundo do trabalho.

O resultado desta análise foi demonstrado por meio de uma árvore hierárquica de palavras, que foi subdividida em duas subclasses de palayras similares (subclasses A e B). Para enriquecer o entendimento, à frente de cada palayra foram indicadas algumas das falas dos egressos associadas a este termo, alếm do coeficiente de correlação de Pearson.

$\mathrm{Na}$ subclasse A, ilustrada na figura 2, as palavras evocam à aquisição de conhecimentos e atitudes. Os conhecimentos estão relacionados à profissão e, assim, à oportunidade de efetivação no trabalho. Mas a formação vai além, e o curso oportunizou a aquisição de novas atitudes, que resultaram autonomia, independência e possibilidades de tomada de decisões.

Figura 2 - Árvore hierárquica de palavras por similaridade - Subcategoria "Benefícios adquiridos pela formação profissional” - Subclasse A

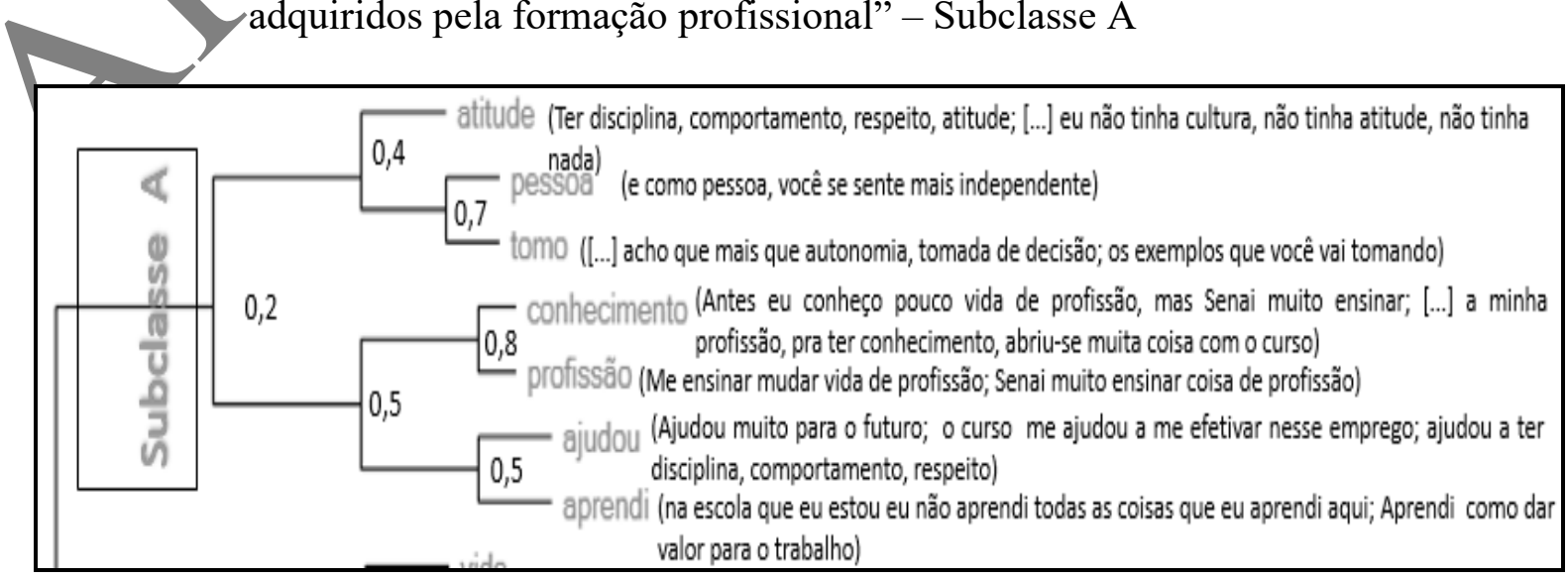

Fonte: resultado da pesquisa, a partir da utilização do QSR NVivo versão 12 
A subclasse B, ilustrada na figura 3, constata mudanças importantes em suas vidas: o curso possibilitou o convívio de pessoas com vários tipos de deficiência no mesmo ambiente de formação; foram expostos e tiveram a oportunidade de descobrir suas capacidades e potencialidades individuais e como grupo; além disso, os conhecimentos adquiridos e o reconhecimento das indústrias pela formação ofertada pelo SENAI abriu portas para sua ascensão ao mundo do trabalho e oportunidade de efetivação no emprego. A estes aprendizados, acrescenta-se o desenvolvimento de autonomia e independência.

Figura 3 - Árvore hierárquica de palavras por similaridade - Subcategoria "Benefícios adquiridos pela formação profissional" - Subclasse B

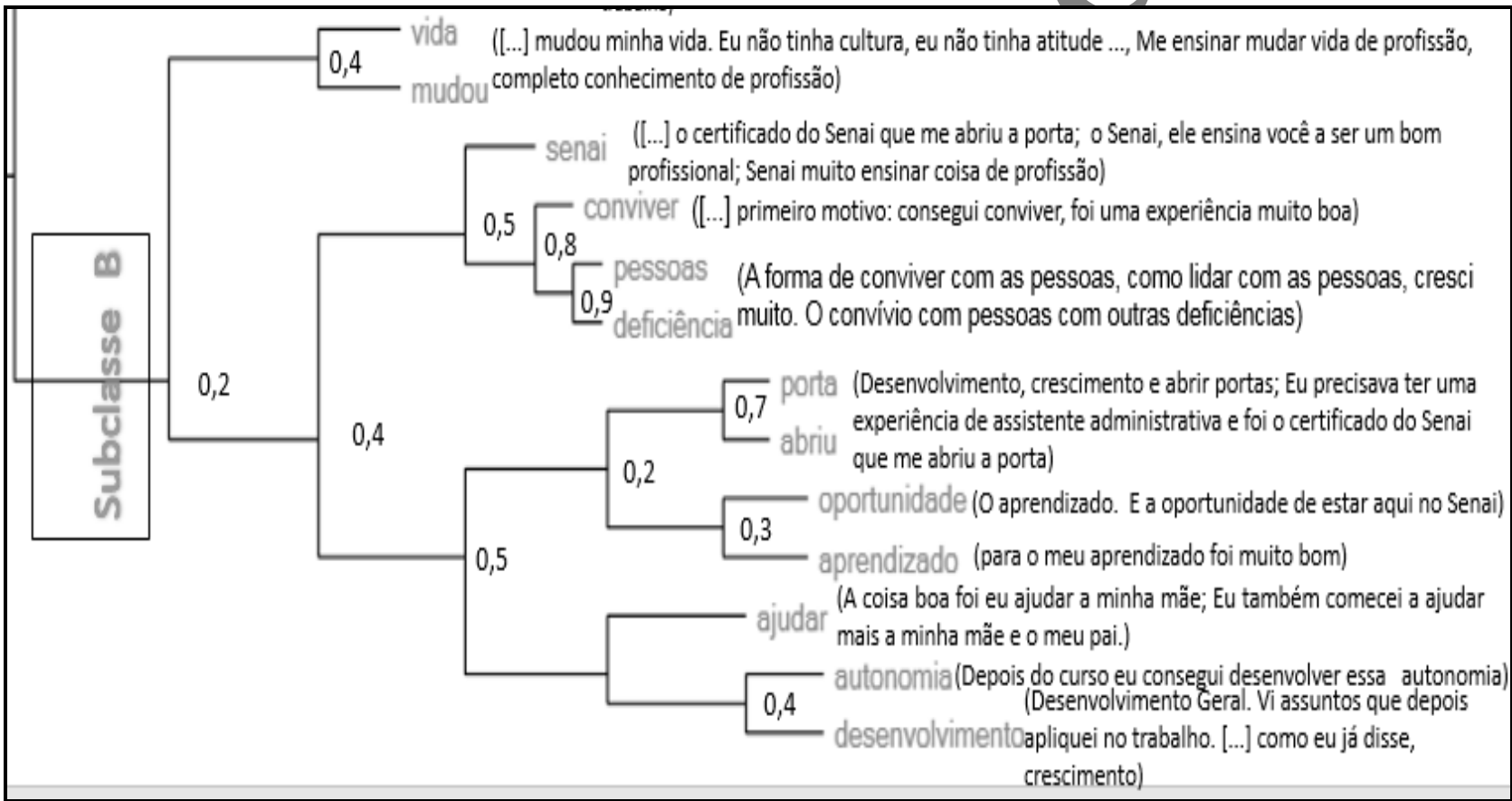

Fonte: resultado da pesquisa, a partir da utilização do QSR NVivo versão 12

Deve-se destacar o direito à profissionalização do jovem e o papel da sociedade na garantia destes direitos, conforme estabelecido pelos artigos 205 e 227 da Constituição Federal de 1988 e artigo $1^{\circ}$. da LDB. Conforme o artigo 53 do Decreto Federal no. 9.579/2018, a aprendizagem profissional destina-se prioritariamente a jovens entre 14 e 18 anos incompletos, que buscam capacitação para o primeiro emprego e que estejam frequentando o ensino médio, caso já tenham concluído o ensino fundamental, observadas as exceções legais. Aranha (2001, p. 170) lembra que "não adianta prover igualdade de oportunidades, se a sociedade não garantir o acesso da pessoa com deficiência a essas oportunidades". Ou seja, mais do que a luta pela igualdade, deve-se buscar a equidade. 


\section{Inclusão no ambiente escolar}

Com o objetivo de verificar como ocorreu a inclusão no ambiente escolar, os egressos foram questionados sobre as dificuldades que tiveram durante o período de aprendizagem e se foi necessária a utilização de algum tipo de suporte ou adaptação para acompanhamento do curso, conforme indicado na figura 4.

Figura 4 - Gráfico da distribuição dos egressos por tipo de deficiência e necessidade de suporte durante o curso

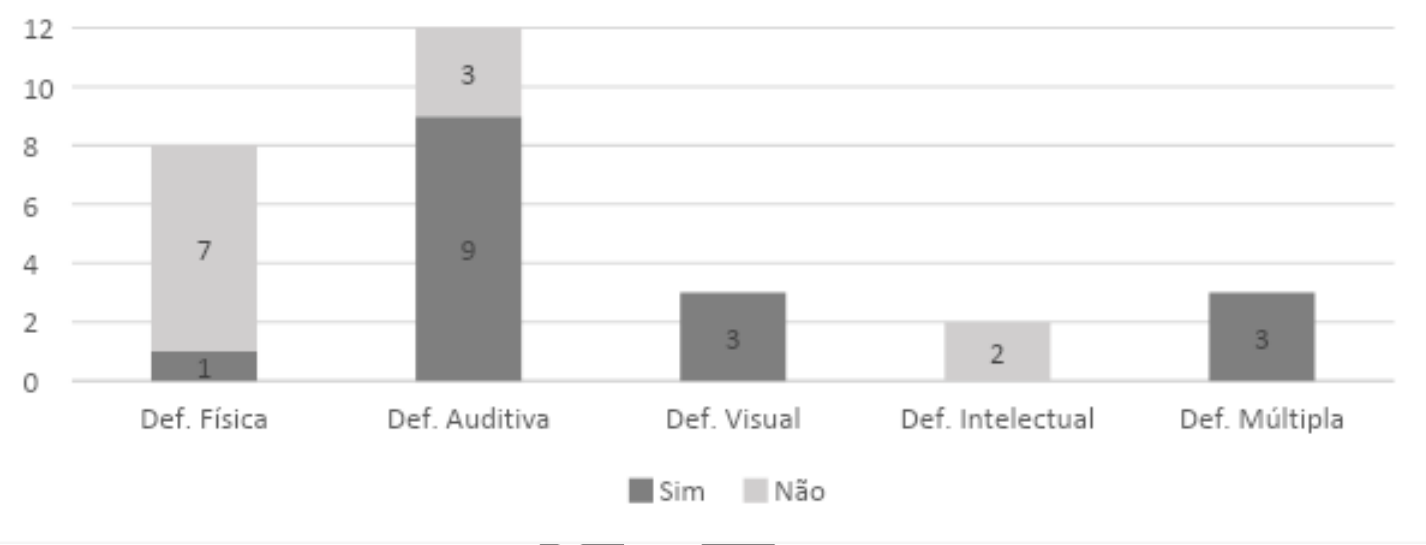

Fonte: resultado da pesquisa

O grupo de egressos que relatou a necessidade de mais suporte está concentrado nos egressos com deficiência auditiva (56\%); os PcD com deficiência auditiva sem oralidade relataram dificuldades relacionadas à comunicação e, em algumas situações específicas, a falta ou dificuldade do intérprete de libras; já os com oralidade, relataram que as dificuldades de comunicação foram mítigadas com ações relacionadas ao seu posicionamento em sala de aula, ao uso de recursos de techologia assistiva (sistemas $\mathrm{FM}^{5}$ para os egressos com implante coclear ou uso de aparelhos de amplificação sonora individual), quando necessário, e ao cuidado do professor em falar de maneira pausada e sempre de frente para eles. Em relação aos conteúdos ministrados, foram citados conceitos matemáticos e aplicativos de informática:

Nem era dificuldade na matéria, era dificuldade no uso do computador, porque até então eu não tinha muito conhecimento. Mas também deslanchou, assim eu peguei, porque se fica se perguntando será que eu vou

\footnotetext{
${ }^{5}$ Sistema FM: sistema de frequência modulada - ferramenta de tecnologia assistiva que pode ser utilizada por pessoas com deficiência auditiva que fazem uso de próteses auditivas convencionais, sistema BaHa ou implante coclear; auxilia na restrição de sons captados pelo ambiente. Em sala de aula, por exemplo, o usuário pede para o professor pendurar um pequeno microfone no pescoço e acrescenta uma peça no aparelho que utiliza. O som ambiente deixa de ser captado, dando ênfase exclusiva à voz do professor.
} 
conseguir? Mas eu peguei e fui, nem posso dizer que foi uma dificuldade, foi uma insegurança. Dificuldade de estudar não achei, não. (E-03, visual).

Não tinha material em Braile. Eu chegava em casa, e todas as minhas coisas, tem um monte de material em braile, daqui do Senai, porque eu preparei, eu fiz. (E-03, visual).

Para mim é matemática, eu não entendo nada de matemática. Eu tinha suporte: usava FM, sentava mais próxima da professora e a professora sempre falava olhando de frente para os alunos e devagar. (E-05, auditiva).

Eu tenho mais dificuldade de entender a matéria de matemática, as vezes eu fico perguntando para professora o que é um assunto. [...] Eu entendo melhor mais ouvir. Eu tinha suporte: usava FM, sentava mais próxima da professora e a professora sempre falava olhando de frente para os alunos e devagar. (E-08, auditiva).

Raciocínio lógico e comunicação. Eu usava um suporte para os pés e ajuda da professora. (E-11, múltipla).

Tive mais dificuldade em contas, porcentagem, essas coisas. E apresentação em público. Tinha que apresentar, inclusive, eu me superei aqui. Porque eu tinha trauma de falar em público. (E-13, física).

Falta de intérprete, professora) sabe pouco libras. Eu necessitava do intérprete de libras. (E-15, auditiva).

Falta de comunicar. Tinha a necessidade do intérprete de libras. (E-18, auditiva).

Os egressos com deficiência auditiva com oralidade, deficiência múltipla e intelectual apontaram como maior dificuldade questões direcionadas com o raciocínio lógico e matemático e com o Português, que podem estar relacionados à baixa escolaridade ou má qualidade da educação bâsica, já que todos eles pertencem ao grupo do programa Meu Novo Mundo, cujas carências educacionais foram detectadas durante as avaliações diagnósticas educacionais e, em função disso, a formação planejada em 3 anos.

Estudos apontam que estas pessoas apresentam maiores dificuldades nas habilidades que requeiram atenção, memória, raciocínio, generalização e abstração, tendo, portanto, necessidades específicas para o aprendizado, que deveriam ter sido supridas por uma educação básica que disponibilize recursos pedagógicos e de acessibilidade que eliminem as barreiras para sua plena participação na escola (BRASIL, 2014a).

A análise hierárquica de palavras por similaridade, calculada pelo coeficiente de correlação de Pearson, utilizada para auxílio na interpretação desta subcategoria, também gerou 2 subclasses de palavras por similaridade (subclasses A e B). Para enriquecer o 
entendimento, à frente de cada palavra foram indicadas algumas das falas dos egressos associadas a cada um dos termos.

Conforme indicado pelos relatos, na subclasse A encontram-se relacionadas palavras que remetem aos obstáculos encontrados durante o período de formação; na subclasse B, por sua vez, as palavras referem-se aos recursos e estratégias utilizados para mitigar essas dificuldades, sendo o professor personagem fundamental no processo.

A figura 5 apresenta um recorte da árvore hierárquica de palavras e contém a Subclasse A: evidencia-se os obstáculos vivenciados durante a formação.

Figura 5 - Árvore hierárquica de palavras por similaridade - Subcategoria 'Inclusão no ambiente escolar" - Subclasse A

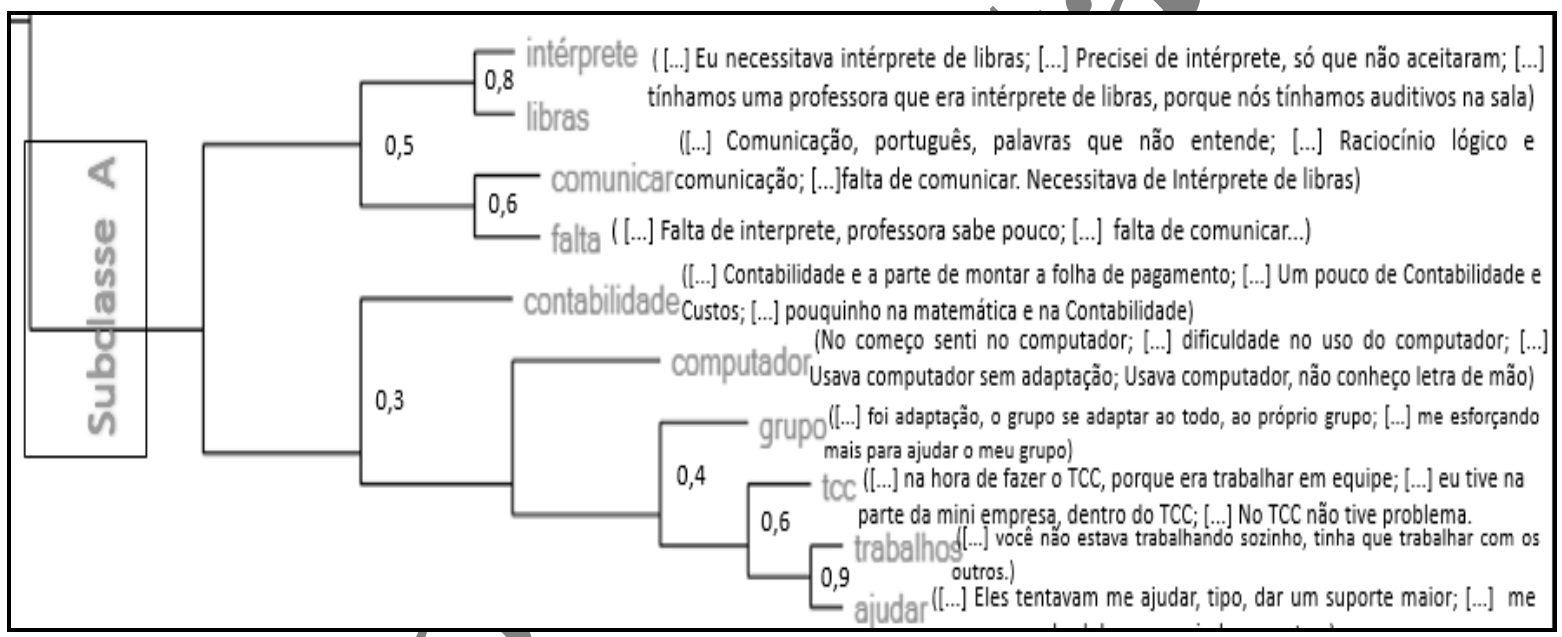

Fonte: resultado da pesquisa, a partir da utilização do QSR NVivo versão 12

A principal dificuldade recorrentemente reportada relaciona-se às barreiras de comunicação. Para os egressos con deficiência auditiva sem oralidade, o intérprete de libras aparece como problema e solução: alguns egressos relataram falta de intérprete ou intérpretes sem a capacitação adequada; outros, porém, enfatizaram a existência de intérpretes durante toda a formação

As ferramentas de tecnologia, que podem ser usadas como recursos adaptativos, foram indicadas como obstáculos num primeiro momento, mas, para os egressos que se utilizavam destes, tornou-se instrumento de auxílio no processo de aprendizagem. Os trabalhos em equipe também foram reportados como dificuldades devido à necessidade de um tempo de adaptação e conhecimento das características de cada colega de curso e o esforço a ser demandado para cumprimento das atividades em equipe. A prática de realizar todas as atividades em grupo denota a preocupação com um espaço para vivência de valores como respeito, comprometimento, adaptação, encontrados nas falas de alguns dos egressos. 
A figura 6 apresenta um recorte da árvore hierárquica de palavras e contém a Subclasse B: as correlações aqui indicadas remetem aos recursos e estratégias utilizados para mitigar os obstáculos correlacionados na subclasse A.

Figura 6 - Árvore hierárquica de palavras por similaridade - Subcategoria "Inclusão no ambiente escolar" - Subclasse B

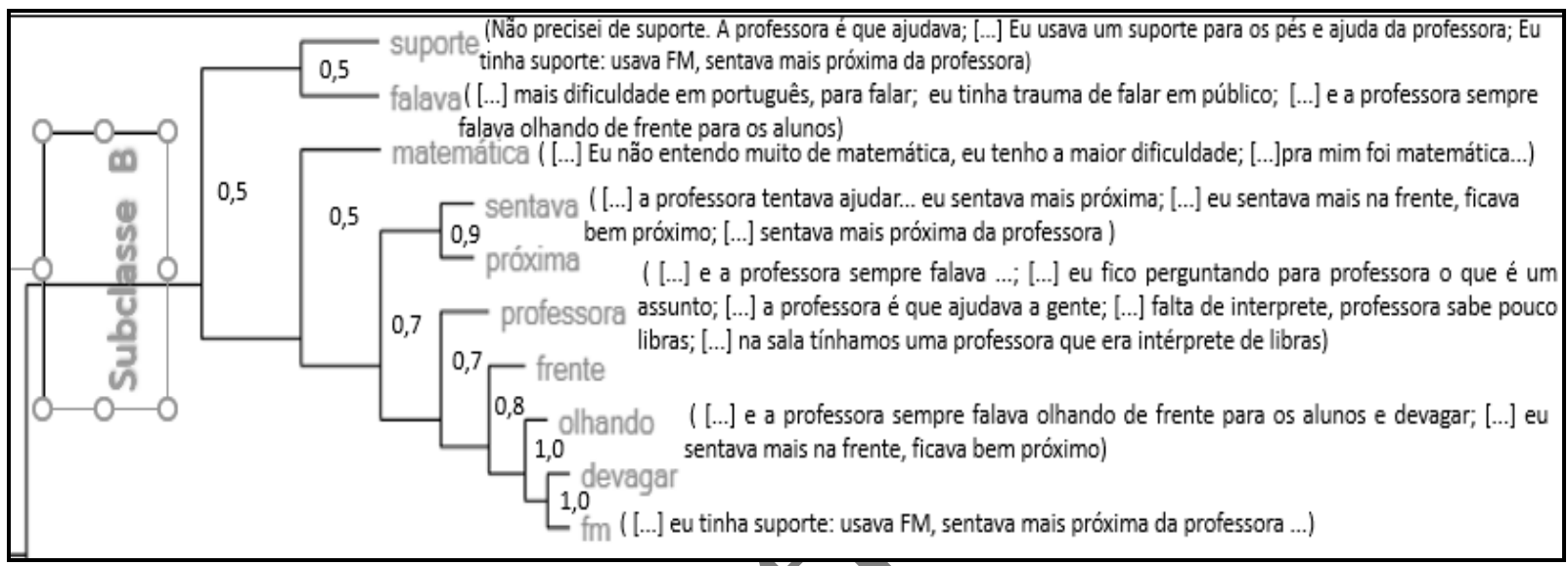

Fonte: resultado da pesquisa, a partir da utilização do QSR NVivo veŕsão 12

Além dos obstáculos elencados na subclasse A, este grupo de palavras correlaciona dificuldades cognitivas associadas às linguagens matemáticas e raciocínio lógico, conforme indicado na nuvem de palavras apresentada anteriormente na figura 5, com o suporte e recursos de tecnologia assistiva e estratégias pedagógicas que foram utilizadas ao longo da formação. Nota-se que, para os egressos, a presença e participação de professores capacitados foi percebido como diferencial no processo de aprendizado durante o curso.

Cada pessoa com deficiêncla possui características que lhe são muito particulares, pois estão relacionadas á sua história de vida, autonomia e ao seu modo de aprender, e devem ser consideradas e tratadas no processo educacional. Em consonância com Lima e Cappelle (2013), entendemos que não é a existência de recursos de suporte e adaptação que vai garantir uma escola inclusiva, mas o atendimento da necessidade requerida pelo aluno, em sua particularidade, tendo deficiência ou não.

Para atender a esse contexto, faz-se necessária a presença de professores que se empenhem e invistam no potencial de cada aluno; assim, mais que um instrutor, o professor deve atuar como um facilitador do processo de aprendizagem. O professor vê-se desafiado a desenvolver habilidades para planejar a participação de todos os alunos, dar suporte às suas aprendizagens, sem lhes fornecer respostas predeterminadas, mas motivando-os a estarem ativamente envolvidos em compreender suas experiências (SENAI, 2015). 
Tendo em vista que o processo de educação inclusiva é muito recente, pode-se inferir pelos dados analisados que, mesmo com falhas durante o período de formação, os egressos foram expostos a um ambiente educacional inclusivo.

\section{Contribuições da Educação Profissional do SENAI na empregabilidade dos egressos}

Segundo Assis (2012), a escola desempenha importante papel na formação do ser humano, independentemente de ter ou não deficiência. Para a pessoa com deficiência, o tipo de formação recebida na Educação Profissional possibilitará que ela se reconheça como sujeito social, uma vez que poderá, por meio do trabalho, constituir-se social e civilmente. Assim, as instituições de Educação Profissional "devem proporcionar aos educandos formas de aprendizagens significativas, preparando-os para a vida e para a inserção na sociedade em geral" (ASSIS, 2012, p. 26).

Durante as entrevistas, ao exporem suas concepções acerca de sua empregabilidade, grande parte da amostra caracterizou as ações dos Cúrsos de Aprendizagem Industrial do SENAI-SP como um diferencial em seu processo de formação. Também fica evidenciado o reconhecimento da qualidade do curso e a importância dada pela formação na empregabilidade dos egressos:

Ver como o funcionário se comporta na empresa, como a empresa se comporta com o funcionário, aqui no SENAI se trabalha muito isso. Muito bom, o SENAI é maravilhoso. Ele trabalha muito isso, a educação, [...]Ele mostra, ele fala, deixa bem claro como que a empresa tem que tratar o

- funcionário e deixa bem claro como que o funcionário tem que se comportar dentro da empresa. (E-02, física).

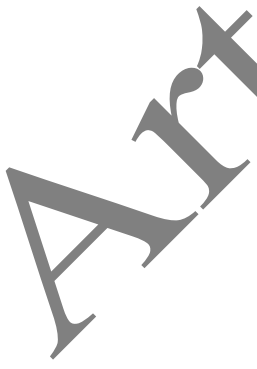

[..] Essa oportunidade para pessoas com deficiência, endereçada para o mundo profissional, é muito importante, porque deu importância à gente, porque antes a gente não tinha essa importância. A gente não tinha importância para empresa, você entregando o currículo, você nunca era chamada porque tem deficiência, e não tem acessibilidade [...]. Se vocêficar desempregada hoje e amanhã já for procurar e ter no seu currículo que você se formou no SENAI, de imediato você é contratada, com certeza. [...] O que acho mais importante em relação à formação do SENAI acho que é a disciplina, postura, o próprio conteúdo. (E-13, física).

[...] Eu percebi que quando coloquei o SENAI no meu currículo, abriu muitas portas. Além do que eu aprendi, abriu muitas portas. Foi um ponto positivo também. Eu acredito no SENAI. (E-14, auditiva).

[...] ]o nome SENAI é muito forte, então abre portas, porque, por exemplo, quando eu cheguei aqui para concorrer à vaga, foi o que me abriu a porta. Porque eu precisava ter uma experiência de assistente administrativa e foi o 
certificado do Senai que me abriu a porta aqui, senão não teria conseguido esse emprego. (E-22, física).

Ajudou a conseguir trabalho. SENAI foi a porta de entrada. Desenvolvimento Geral. Vi assuntos no curso que depois apliquei no trabalho [...]. E fora que o SENAI, ele é bem rígido no sentido de disciplina [...]. É a disciplina que mantém ali [...]. E é um ensino técnico mesmo, a metodologia [...]. O SENAI tinha uma estrutura para atender todo mundo. (E-27, física).

Destaca-se, nos relatos refere-se à qualificação dos professores, que entendem terem sido capacitados para ministrar aulas para pessoas com deficiência:

Eu acho que eles [professores] foram muito capazes, muito sábios, e não deixou a desejar em nada [...]. Os professores foram treinados para dar aulas para $P c D$. (E-01, física).

Quando eu fui fazer o assistente eu já estava terminando a faculdade, eu estava no último ano da faculdade, mas assim, eu só comentava com a professora do SENAI. Eles passam na faculdade a matéria, e o curso, ele me trouxe muito mais conhecimento. (E-22, física).

Você cresce muito, você amadure muito rápido, acredito eu que sem o curso, sei lá, você tem uma postura diferente no serviço [...]. E os exemplos que você vai tomando, que eu que lembro que tomava quando eu era aprendiz, hoje em dia eu continuo com a mesma atitude. (E-24, visual).

Lá no curso a gente fazia a parte técnica, a parte prática e parte dos nossos sentimentos. A gente falava: o que você quer pro futuro? A professora de informática até fez uns vídeos. (E-28, intelectual).

Entende-se que essas ações estão em linha com a aplicação de um sistema de educação inclusiva, que preza a valorizaçâo das potencialidades dos alunos em detrimento de suas incapacidades. Algựs egressos trouxeram em suas falas exemplos do cuidado da instituição com a educação profisssional inclusiva:

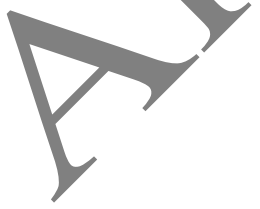

O SENAI sempre abriu as portas para os PcD. Ele é maravilhoso, eles suprem a sua necessidade mesmo. Que nem aqui antes não tinha fretado para ir embora [...]. O SENAI foi atrás de uma empresa, conseguiu um fretado [...] sem custo nenhum para o aluno [...] são poucas instituições que oferecem direto para PCD. É o essencial. Para engrenar você no ambiente de trabalho, porque é muito triste você entrar numa empresa que fala, a gente aceita PcD, mas tem que ser dos nossos critérios. E o SENAI não, ele deu um jeito de colocar todo mundo lá. (E-23, auditiva).

[...] a escola tentava fazer com que nós não se sentisse excluidos e mostrar para eles que nós não era diferente, nós era a mesma coisa, tanto que tem um exemplo, estava tendo um campeonato de futebol lá, e começaram a zoar porque a nossa classe ia entrar [...]. Isso revoltou muita gente, tanto é que cancelaram o torneio e chamaram os responsáveis para conversar [...] e ai mostrou mesmo que, que o modo do SENAI lidar é, é bem profissional, 
independente da idade você tem que ter a maturidade, saber o que você está fazendo [...] porque não é certo fazer isso. (E-24, visual).

O SENAI tinha uma estrutura para atender todo mundo [...]. O SENAI conseguiu um transporte pra gente [...] o SENAI conseguiu um ônibus exclusivo pra nós, iam seis, oito pessoas só no ônibus, conseguiram com a Prefeitura [...]. (E-27, física).

Pela análise hierárquica de palavras por similaridade, foi possível identificar os temas prevalentes nas unidades de registro e contexto apresentadas ao longo deste tópico e relacionadas em duas subclasses de palavras similares (subclasses A e B). Para enriquecer o entendimento, à frente de cada palavra foram indicadas algumas das falas dos egressos associadas a cada um dos termos.

Conforme indicado pelos relatos, na subclasse A encontram-se relacionadas palavras que suportam, na visão dos egressos, a contribuição da formação para a empregabilidade; na subclasse B, as palavras correlacionadas indicam, na concepção dos egressos, a valorização de ações realizadas pelo SENAI para as pessoas com deficiência.

A figura 7 apresenta o recorte da árvore hierárquica de palavras referentes à Subclasse A: contribuições para a empregabilidade.

Figura 7 - Árvore hierárquica de palávras por similaridade - Subcategoria "Contribuições da educação profissional do SENAI para a empregabilidade dos egressos" -

Subclasse A

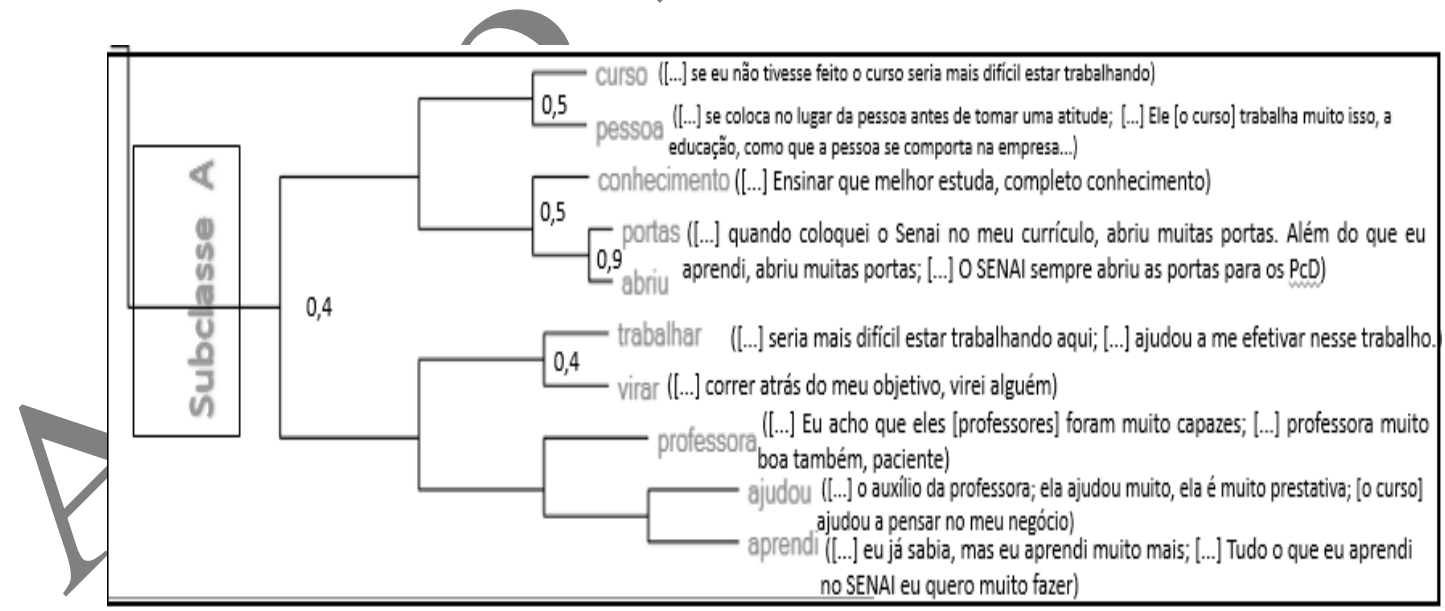

Fonte: resultado da pesquisa, a partir da utilização do QSR NVivo versão 12

A correlação de palavras nesta subclasse suscita a contribuição que a formação profissional tem na empregabilidade dos egressos: o curso possibilitou a aquisição de conhecimentos que "abriu portas" para o mundo do trabalho, para seu empoderamento enquanto cidadão, manifesto na expressão "virar alguém". 
Há o reconhecimento da metodologia utilizada pelo SENAI, na figura do professor, mediador e facilitador no processo de aprendizagem e capacitado para a educação de PcD.

A figura 8 apresenta o recorte da árvore hierárquica de palavras referentes à Subclasse B: valorização de ações do SENAI para as pessoas com deficiência.

Figura 8 - Árvore hierárquica de palavras por similaridade - Subcategoria "Contribuições da educação profissional do SENAI para a empregabilidade dos egressos" -

Subclasse B

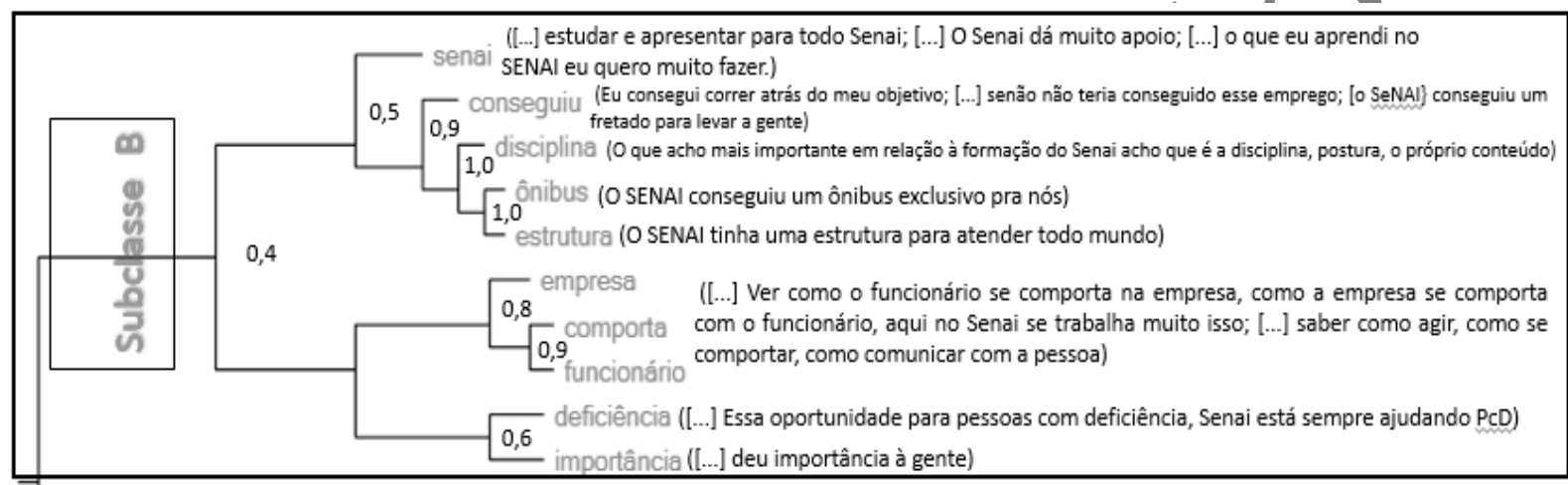

Fonte: resultado da pesquisa, a partir da utilização do QSR NVivo zersão 12

As palavras correlacionadas nesta subclasse permitem inferir, na concepção dos egressos, a partir de seus relatos, a valorização de ações que foram sendo realizadas pelo SENAI-SP, ao longo da formação, no sentido de proporcionar aos alunos melhores condições para a aprendizagem.

Foram valorizadas as condições de acessibilidade (ônibus) propiciadas pela instituição, os recursos e a metodologia disponibilizados para a formação, no sentido de atender a necessidade de cada aluno, e a seriedade do programa, referenciadas nas palavras estrutura e disciplina, além-da vivência da prática laboral, permitindo ao aluno entender a dinâmica do mundo do trabalho, com seus direitos e deveres enquanto profissional. Por meio dessas ações, é percebida, por este grupo de egressos, a importância dada à $\mathrm{PcD}$ pelo SENAI-SP.

Faz-se notória a contribuição da educação profissional, em especial dos cursos de Aprendizagem Industrial do SENAI-SP, para a empregabilidade da pessoa com deficiência, pois "pode ajudar as pessoas a desenvolver as competências requisitadas pela vida e pelo mundo do trabalho, já que, para o bom profissional, interessa não somente o desenvolvimento de competências profissionais, mas também de competências gerais que garantam a formação de um ser humano íntegro e comprometido" (ZANOTE, 2011, p. 136).

\section{- Nuvens de palavras}


Com o auxílio do software NVivo 12, foram construídas nuvens de palavras, com o objetivo de identificar as principais palavras relacionadas às categorias que ora são sintetizadas:

\begin{tabular}{|c|c|c|}
\hline $\begin{array}{l}\text { Figura } 9 \text { - Nuvem de palavras } \\
\text { relacionadas aos benefícios da } \\
\text { formação profissional na concepção } \\
\text { dos egressos }\end{array}$ & $\begin{array}{l}\text { Figura 10: } \text { Nuvem de palavras } \\
\text { relacionadas } \\
\text { encontradas no percurso da formação } \\
\text { profissional na concepção dos egressos }\end{array}$ & $\begin{array}{l}\text { Figura } 11-\text { Nuvem de Palavras- } \\
\text { Concepções dos egressos sobre as } \\
\text { Contribuições da Educação Profissional } \\
\text { do SENAI/na empregabilidade }\end{array}$ \\
\hline 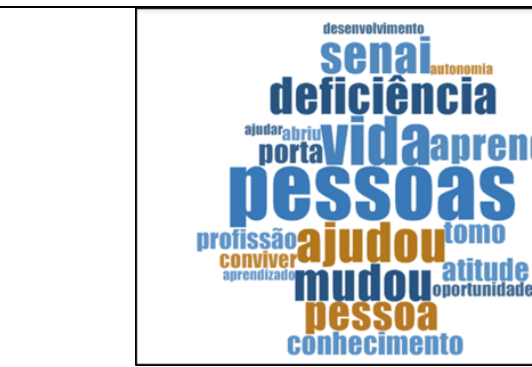 & 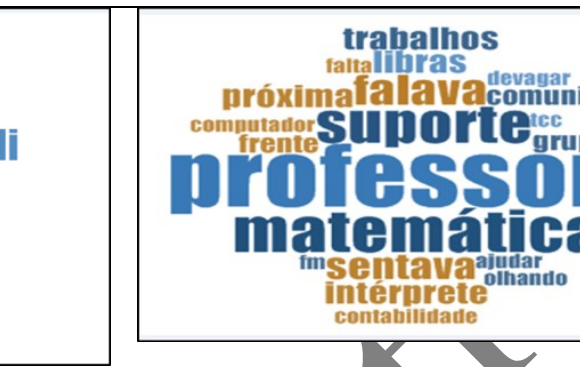 & 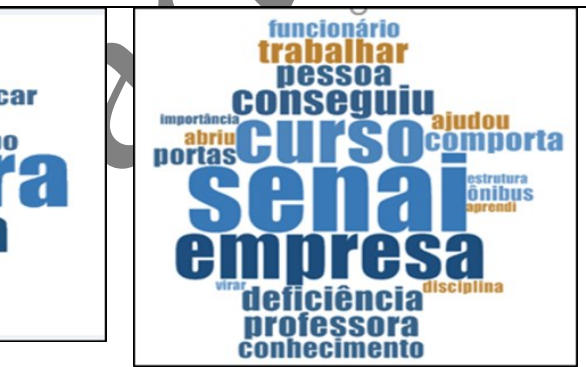 \\
\hline
\end{tabular}

Fonte: resultado da pesquisa, a partir da utilização do QSR NVivô versão 12

É possível inferir, a partir das considerações feitas, que a lei pode garantir a inserção da pessoa com deficiência no mercado de trabalho, mas a inclusão deste sujeito é um processo mais complexo, que requer quebras de barrerras de toda ordem, que permita a igualdade de oportunidades para a PcD, a fim de que ela seja aceita pelos demais colaboradores e que seu trabalho seja reconhecido, valorizado e tenha sentido nas organizações.

\section{Considerações finais}

Este artigo teve como objetivo apresentar, na concepção de PcD egressas de cursos de formação profissional, a contribuição da educação profissional para sua inclusão no mundo do trabalho

Entende-se que esse objetivo foi atingido na medida em que foi possível identificar que, na data da entrevista, $71 \%$ dos egressos estavam empregados em sua área de formação profissional; 4\% dos egressos estavam empregados, porém em áreas diferentes da sua formação profissional, e $25 \%$ dos egressos ainda estavam fora do mercado formal de trabalho após a conclusão da formação profissional.

De modo particular, no que se refere à inclusão no mundo do trabalho, faz-se necessário a quebra de barreiras para que elas se reconheçam e sejam reconhecidas como 
parte integrante da sociedade produtiva. PcD ainda são vistas como incapazes de produzir, questão muitas vezes associadas à falta de qualificação e capacitação profissional. Assim, entende-se que educação e formação profissional podem contribuir para uma mudança nesse cenário de exclusão; de modo especial, educação profissional de qualidade.

Não obstante existam instrumentos legais disponíveis no país para facilitar o acesso e a permanência das pessoas com deficiência à escola e ao trabalho, os instrumentos por si só não são suficientes para eliminar as barreiras impostas a este público. Faz-se necessário o aprofundamento e disseminação de práticas que, de fato, viabilizem as experiencias de inclusão na educação e no trabalho para as PcD. Por meio desta pesquisa, evidencia-se que instituições de educação que cumprem a lei com rigor e seriedade suscitam ambientes mais inclusivos, onde alunos com as mais variadas características podem conviver e desenvolver suas potencialidades e capacidades.

Observa-se que na formação profissional ofertada a essegrupo de sujeitos, para além da aquisição de conhecimentos e habilidades, o grande diferencial foi a possibilidade do resgate de sua autoestima, por meio do reconhecimento de suas potencialidades e capacidades, do resgate de sua cidadania. Isso só é possível mediante a vivência num ambiente inclusivo, que perpassa a sala de aula e se dissemina em todo o ambiente escolar. A formação e capacitação de todas as pessoas envolvidas no processo educacional, a preocupação genuína com a necessidade individual e com o convívio como grupo também é um diferencial que deve ser considerado quando se pensa em educação profissional inclusiva.

Os sujeitos entrevistados sinalizaram que a formação recebida é peça chave para seu processo de desenvolyimento. Para os que estão incluídos no mundo do trabalho, os sujeitos percebem valor nơ que oferecem às empresas, sentem-se inseridos no processo laboral, e como tal, tem legítimas aspirações de desenvolvimento e crescimento profissional.

Considera-sé que programas de educação profissional que, além da formação profissionalizante, priorizam o desenvolvimento integral do indivíduo, respeitando suas singularidades e características, contribuem significativamente para a formação cidadã do aluno e a sua empregabilidade. Ao se proporcionar as mesmas oportunidades a todos os alunos, talentos e habilidades são descobertos e plenos cidadãos e profissionais são formados.

AGRADECIMENTOS: Coordenação de Aperfeiçoamento de Pessoal de Nível Superior (CAPES) e Conselho Nacional de Desenvolvimento Científico e Tecnológico (CNPq). 


\section{REFERÊNCIAS}

ABBUD, C. F. A pedagogia da empregabilidade no site da Associação Brasileira de Recursos Humanos (ABRH). 2017. 180 f. Tese (Doutorado em Educação) - Universidade Federal do rio Grande do Sul - UFRGS, Porto Alegre, 2017.

ALKMIM, G. V. Empregabilidade dos egressos dos cursos superiores de Tecnologia em diferentes regiões do Estado de Minas Gerais: o caso do curso de Análise e Desenvolvimento e Sistemas. 2015. 238 f. Tese (Doutorado em Educação) - Universidade Federal de Minas Gerais - UFMG, Belo Horizonte, 2015.

ASSIS, S. T. G. de. A educação profissional de pessoas com deficiência: processos de inclusão. 206 f. Dissertação (Mestrado em Educação) - Universidade Estadual do Pará UEPA, Belém, PA, 2012.

BARDIN, L. Análise de conteúdo. São Paulo: Edições 70 - Almedina, 2016.

BRASIL. Câmara dos Deputados. Constituição da República Federativa do Brasil de 1988. 52. ed. Brasília: Edições Câmara, 2017.

BRASIL. Lei n. 13.146, de 06 de julho de 2015. Brasília, 2015. Disponível em: http://www.planalto.gov.br/ccivil_03/_Ato2015-2018/2015/Lei/L13146.htm. Acesso em: 10 nov. 2017.

BRASIL. Ministério da Educação. Lei 9.394, de 23 de dezembro de 1996. Brasília: MEC, 1996. Disponível em : http://www.planalto,gov.br/ćcivil_03/Leis/L9394.htm. Acesso em: 02 abr. 2020.

BRASIL. Ministério da Educação. Política Nacional de Educação Especial na Perspectiva da Educação Inclusiva. Brasília, DF, 2014a. Disponível em: http://portal.mec.gov.br/index.p $\mathrm{hp}$ ?option=com_docman \& view $=$ download\&alias $=16690$-politica-nacional-de-educacao-espec ial-na-perspectiva-da-educacao-inclusiva-05122014\&Itemid $=30192$. Acesso em: 10 jun. 2020.

BRASIL. Ministério da Saúde. Conselho Nacional de Saúde. Resolução n. 466, de 12 de dezembro de 2012. Brasília, Diário Oficial da União, 12 dez. 2012. Disponível em: http://conselho.saude.gov.br/resolucoes/2012/Reso466.pdf. Acesso em 02 abr. 2020.

BRASIL. Minístério do Trabalho e Emprego. Relação Anual de Informações Sociais (2017) Análise dos principais resultados. Brasília, MTb, set. 2018. Disponível em: http://pdet.mte.gov.br/rais?view=default. Acesso em 02 abr. 2019.

BRASIL. Secretaria Especial dos Direitos Humanos. Convenção sobre Direitos das Pessoas com Deficiência comentada. Brasília: Secretaria Especial dos Direitos Humanos, 2008.

DELORS, J. Educação: um tesouro a descobrir. Relatório para a UNESCO da Comissão Internacional sobre Educação para o século XXI. São Paulo: Cortez, 1998.

GARCIA, J. C. D.; GAlVÃo FILHO, T. A. Pesquisa Nacional de Tecnologia Assistiva. São Paulo: ITS BRASIL/MCTI-SECIS, 2012. 68 p. 
GIL, M. Caminhos da Inclusão: a história da formação profissional de pessoas com deficiência no SENAI-SP. São Paulo: SENAI-SP Editora, 2012. 248p.

INSTITUTO BRASILEIRO DE GEOGRAFIA E ESTATÍSTICA - IBGE. Cartilha do Censo Demográfico 2010 - Características gerais da população, religião e pessoas com deficiência. Rio de Janeiro, 2010. 215p. Disponível em: https://biblioteca.ibge.gov.br/ visualizacao/periodicos/94/cd_religiao_deficiencia.pdf. Acesso em 09 jun. 2020.

JOHANN, J. Programas de Educação Profissional na APAE de Toledo, Paraná. 2011. 104 f. Dissertação (Mestrado em Educação) - Universidade Estadual do Oeste do Paraná UNIOESTE, Cascavel, PR, 2011.

LIMA, M. P.; CAPPELLE, M. C. A. Educação Profissional de Pessoas com Deficiềncia: adaptações para a acessibilidade. Perspectiva, Florianópolis, v. 31, n. 3, p. 1065-1098, 2013.

MEUnOVOMUndo. Projeto Meu Novo Mundo: um olhar diferente para a inclusão. 2014. Disponível em: http://www.meunovomundo.org.br/projeto.html_Acesso em: 10 mar. 2020.

MINAYO, M. C. de S. A inclusão da violência na agenda da saúde: trajetória histórica. Ciência \& Saúde Coletiva, v. 11, p. 1259-1267, 2006.

MINARELLI, J. A. Empregabilidade: o caminho das pedras. 6. ed. São Paulo: Gente, 1995.

NEVES-SILVA, P; PRAIS, F. G.; SILVEIRA, A. M. Inclusão da pessoa com deficiência no mercado de trabalho em Belo Horizonte, Brasil: cenário e perspectiva. Ciênc. Saúde coletiva [online], v. 20, n. 8, p. 2549-2558, 2015. Disponível em: http://www.scielo.br/scielo.php?pi $\mathrm{d}=\mathrm{S} 141381232015000802549 \&$ script=sci_abstract\&tlng=pt. Acesso em: 04 fev. 2020.

OLIVEIRA, F. C. de. Educação profissional de pessoas com deficiência: política e produção acadêmica, no Brasil, pós lei 8.213/1991. 2017. 192 f. Dissertação (Mestrado em Educação) - Universidade de São Paulo, São Paulo, 2017.

OMS. World Health Organization. The World Bank. Relatório Mundial Sobre a Deficiência. Trad. Lexicus Serviços Linguísticos. São Paulo: SEDPcD, 2012. 334 p. Título original: World report on disability, 2011.

ROCHA, L. P.; REIS, M. B. de F.; COSTA, V. B. da. Educação especial e inclusão: diálogos sobre pesquisa, políticas e práticas. Revista Ibero-Americana de Estudos em Educação, [S.1.], v. 15, n. esp. 1, p. 872-883, mar. 2020. ISSN 1982-5587. Disponível em: https://periodicos.fclar.unesp.br/iberoamericana/article/view/13501. Acesso em: 18 jun. 2020. DOI: https://doi.org/10.21723/riaee.v15iesp.1.13501

SALES, P. E. N.; OLIVEIRA, M. A. M. Políticas de educação profissional no Brasil: trajetórias, impasses e perspectivas. In: CARVALHO, M. L. M. (Org.). Cultura, saberes e práticas: memórias e história da educação profissional. São Paulo: Centro Paula Souza, 2011. p. $165-184$.

SASSAKI, R. K. Como chamar as pessoas que têm deficiência? Revista da Sociedade Brasileira de Ostomizados, ano I, n. 1, p. 8-11, 2003. [Texto atualizado em 2009]. 
SASSAKI, R. K. Inclusão: Construindo uma sociedade para todos. Rio de Janeiro: WVA, 2010. 180 p.

SENAI. Serviço Nacional de Aprendizagem Industrial. Departamento Nacional. Método de adequação de curso para inclusão da pessoa com deficiência. Serviço Nacional de Aprendizagem Industrial. Brasília: SENAI, 2015. 172 p., il.

SENAI. Serviço Nacional de Aprendizagem Industrial. Aprendizagem industrial: orientações para as empresas. 5. ed. São Paulo, 2018. 218 p., il.

SENAI. Serviço Nacional de Aprendizagem Industrial Institucional: o que é o senai. 2019. Disponível em: http://www.portaldaindustria.com.br/senai/institucional/ o-que-e-o-senai/. Acesso em: 10 mar. 2020.

SENAI. T. Serviço Nacional de Aprendizagem Industrial. Iniciativas: programas e serviços. 2019a. Disponível em: http://www.portaldaindustria.com.br/senai/institucion al/programas-eservicos/. Acesso em: 10 mar. 2020.

SILVA, R.A.; LUCIFORA, C.A.; REINA, F.T.; Muzzeti, L.R. Marcas sociais de nossos tempos: gênero, sexualidade e educação em âmbito escolar. Revista Ibero-Americana de Estudos em Educação, [S.1.], v. 14, n. esp. 2, p. 1395-1409 jun. 2019. ISSN 1982-5587. Disponível em: https://periodicos.fclar.unesp.br/iberoamericana/article/view/12607. Acesso em: 18 junho 2020. DOI: https://doi.org/10.21723/riaee.v14iesp.2.12607

SILVA, R. S. A inclusão no mercado de trabalho formal e a construção da identidade de pessoas com deficiência: um estudo de caso. 2014. 89 f. Dissertação (Mestrado Profissional em Administração) - Centro Universitário UNA, Belo Horizonte, 2014.

ZANOTE, M. A. Avaliação de competências profissionais de aprendizes com deficiência: um estudo de caso. 2011. 172 f. Tese (Doutorado em Educação) - Universidade Estadual Paulista - UNESP, Marília/SP, 2011.

\section{Como referenciar esse artigo}

MINAYO, M.C.; DEMO, P.; SILVA, R. A. Pessoas com Deficiência (PcD) egressas de uma formação profissional: trabalho e educação. Revista Ibero-Americana de Estudos em Educação, Araraquara, v. 15, n. 4, p. 1703-1729, out./dez. 2020. e-ISSN: 1982-5587. DOI: https://doi.org/10.21723/riaee.v15i4.13816

Submetido em: 30/03/2020

Revisões requeridas em: 25/05/2020

Aprovado em: 16/07/2020

Publicado em: 30/08/2020 


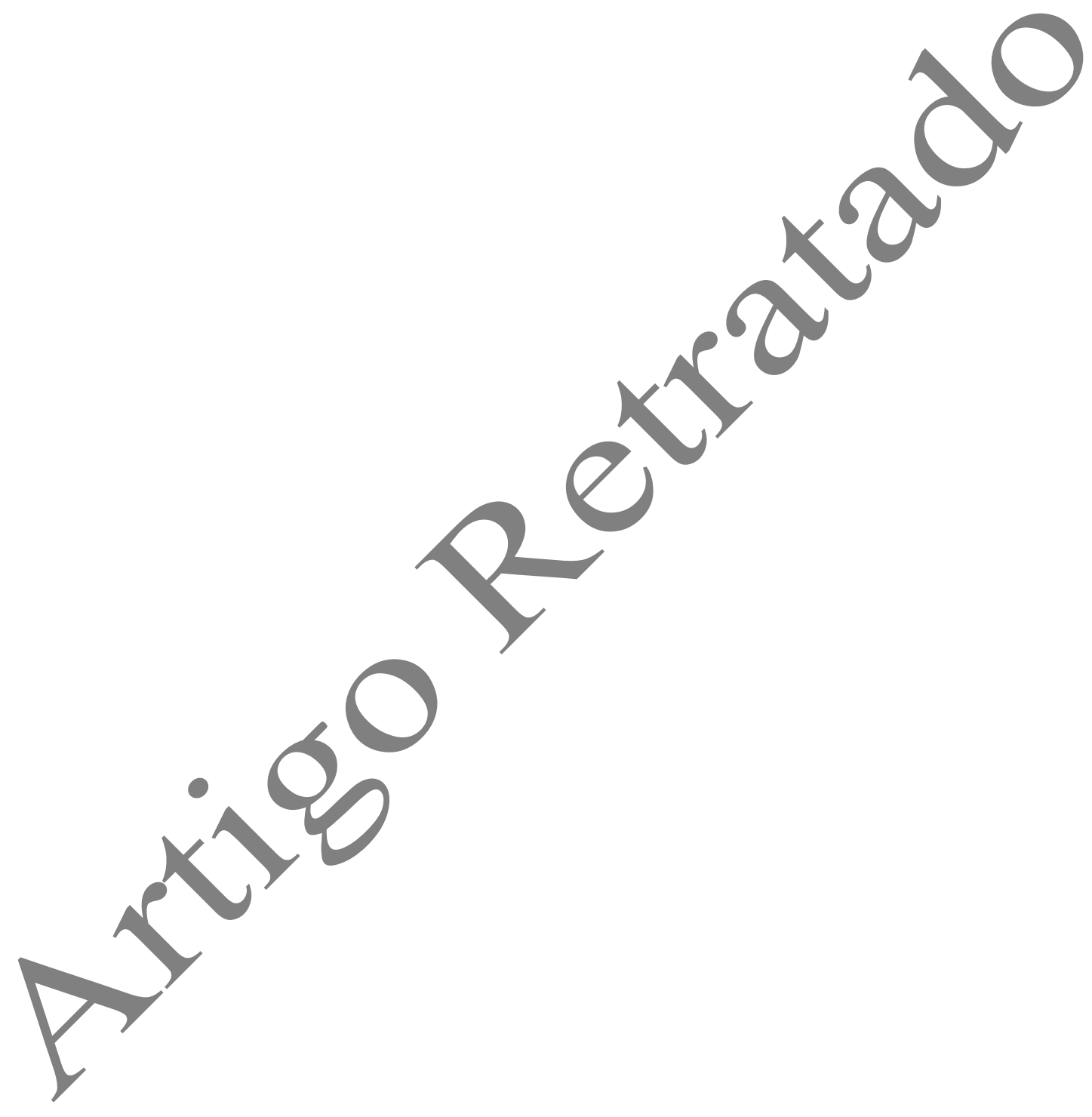

RIAEE - Revista Ibero-Americana de Estudos em Educação, Araraquara, v. 15, n. 4, p. 1703-1729, out./dez. 2020. e-ISSN: $1982-5587$. DOI: https://doi.org/10.21723/riaee.v15i4.13816 